\title{
Native Seychelles tortoises or Aldabran imports? The importance of radiocarbon dating for ancient DNA studies
}

\author{
K. Praveen Karanth ${ }^{* 1}$, Eric Palkovacs ${ }^{1}$, Justin Gerlach ${ }^{2}$, Scott Glaberman ${ }^{1}$, Julian Pender Hume ${ }^{3}$, \\ Adalgisa Caccone ${ }^{1,4}$, Anne D. Yoder ${ }^{1}$
}

The living and extinct giant tortoises of the western Indian Ocean islands have been extensively studied in recent times (Bourn et al., 1999; Austin and Arnold, 2001; Palkovacs et al., 2002; Austin et al., 2003; Palkovacs et al., 2003). Currently, indigenous wild populations of Indian Ocean giant tortoises (genus Dipsochelys) occur only on the island of Aldabra, northwest of Madagascar, with most wild tortoises having become extinct on the Seychelles as early as 1800 , largely through overexploitation by European sailors and settlers (Stoddardt et al., 1979; Austin et al., 2003). Recent molecular genetic studies on Dipsochelys suggest that there is very little genetic variation among extant Indian Ocean tortoises. Palkovacs et al. (2002) analyzed three mitochondrial genes, $12 \mathrm{~S}$ and $16 \mathrm{~S}$ ribosomal RNA (rRNA) and cytochrome $b$ (cyt- $b$ ), and found no variation among captive tortoises assigned to three Dipsochelys species. Austin et al. (2003) looked at cyt- $b$ sequences from modern and museum skins of Dipsochelys from the islands of Aldabra and the Seychelles and found ex-

1 - Department of Ecology and Evolutionary Biology, Yale University, P.O. Box 208105, New Haven, CT 06520, USA

2 - University Museum of Zoology Cambridge, Department of Zoology, Downing Street, Cambridge CB2 3EJ, UK

3 - Bird Group, Department of Zoology, The Natural History Museum, Akeman Street, Tring, Hertfordshire HP23 6AP, UK

4 - YIBS-Ecosave Molecular Systematics and Conservation genetics Laboratory, New Haven, CT 06520, USA

Corresponding author. E-mail address:

praveen.karanth@yale.edu tremely low variation. Work done by Palkovacs et al. (2003) on wild and captive Indian Ocean tortoises showed that the three morphotypes, two of which were purported to represent native Seychelles species and the other one from Aldabra, were genetically identical at the rapidly evolving control region of the mitochondrial DNA (mtDNA) and showed no genetic structuring at eight microsatellite loci. These molecular studies also suggested that surviving populations of giant tortoises on the Seychelles islands might have been derived from Aldabra tortoises (Palkovacs et al., 2002; Austin et al., 2003). This scenario is plausible given that there are historical records of human mediated movement of Aldabra tortoises to the Seychelles and other islands by passing ships (Stoddardt et al., 1979). In more recent times (between 1974 and 1982) Aldabra tortoises were also introduced to Curieuse and Fregate islands of the Seychelles as a conservation measure (Hamber, 1994).

Human-mediated transport of tortoises commenced with the European colonization of these islands. Thus, to study genetics of native Seychelles tortoises one has to examine samples collected from tortoises that were present on these islands before European colonization, as the native tortoises may have been driven to extinction with the advent of European colonization. In fact, molecular analysis of museum samples of tortoises collected from the Seychelles also point towards a close relationship to Aldabran animals (Austin et al., 2003), suggesting that they may have been Aldabran imports rather than native Seychelles tortoises. Thus, 
the most reliable pre-European source of native Seychelles tortoise DNA would be from subfossils recovered from the Seychelles (Austin et al., 2003; Palkovacs et al., 2003). In an effort to decipher the evolutionary origins of native Seychelles tortoises, we attempted amplification of several mtDNA (cyt- $b, 12 \mathrm{~S}$ rRNA, and control region) markers from five putative subfossils collected from the Seychelles.

A total of five bone samples were collected from various islands in the Seychelles (see table 1 and fig. 1 for details). Based on historical and paleontological evidence, these samples were initially assumed to represent native Seychelles tortoises from pre-European times. Samples 1, 2, and 4 were uncovered from dry laterite soil in a cave deposit on Silhouette Island about $20 \mathrm{~m}$ above sea level. Historical records indicate that free-ranging tortoises have not been seen on Silhouette Island since about 1840, thus these samples were assumed to be on the order of 150200 years old. Sample 3 was taken from organic soil about $1 \mathrm{~m}$ below the surface in a marsh deposit on North Island. Historical records suggest that all tortoise populations on North Island were decimated by fire in the 1770 s. Therefore, this sample was suspected to be at least 220 years old. Sample 5 was buried in a coastal sand deposit on Curieuse Island, $1 \mathrm{~m}$ above sea level and $2 \mathrm{~m}$ from the edge of a brackish marsh. It was accompanied by deposits of snails that have been extinct since extensive fires occurred in 1778 and was therefore suspected to be at least 225 years old, rather than derived from Aldabra tortoises introduced to Curieuse in the 1980s. All samples had the weathered appearance expected of subfossil materials. The radiocarbon age of samples $1,3,4$, and 5 were determined by accelerated mass spectrometry at the Rafter Radiocarbon Laboratory, Institute of Geological and Nuclear Sciences Limited, New Zealand. Sample 2 did not yield sufficient biomaterial for carbon dating.

All DNA extractions were conducted in a clean room facility that conformed to the requirements of aDNA laboratory (Austin et al.,
1997). The protocol used for DNA extraction was as in (Yoder et al., 1999) with minor modifications. A dremel was used to clean the outer surface of each subfossil and to cut a small fragment for DNA extraction. These fragments (weighing between 0.5 to 1 grams) were thoroughly washed in ultra pure water, later soaked in $2 \%$ bleach for $5 \mathrm{~min}$, and washed again thoroughly in water. After drying, samples were powdered in a cryogenic impact grinder (SPEX CertiPrep 6750 Freezer/Mills) following manufacturers instructions. The powdered sample was placed inside a dispodialyzer (Harvard/AmiKa, MWCO: 10000 ) with $0.5 \mathrm{M}$ EDTA ( $\mathrm{pH}$ 8) and subjected to decalcification in $200 \mathrm{ml}$ 0.5 M EDTA for 3-4 days at room temperature. The decalcified sample was digested in $4 \mathrm{ml}$ extraction buffer $(10 \mathrm{mM}$ Tris $\mathrm{HCl}, 100$ $\mathrm{mM} \mathrm{NaCl}, 0.5 \% \mathrm{SDS}$ ) with $100 \mu \mathrm{l}$ of $20 \mathrm{mg} / \mathrm{ml}$ proteinase $\mathrm{K}$ at $55^{\circ} \mathrm{C}$ for $12-24$ hrs. After the digestion step, the sample was extracted twice with phenol-chloroform, followed by concentration in Centricon-30. No tortoise DNA had been extracted in the facility prior to this study. To prevent cross-contamination, each sample was subjected to the above procedure, independent of the other samples, with a gap of one week between extractions, and with an intervening decontamination of the facility. A negative extraction control was always included in each extraction rounds. Seven different mtDNA fragments of increasing size were attempted for PCR amplification (tables 1 and 2).

A typical PCR mix of $50 \mu \mathrm{l}$ volume, consisting of $1 \times$ buffer, $0.2 \mathrm{mM}$ dNTPs, $0.4 \mu \mathrm{M}$ of each primer, $2 \mu \mathrm{l}$ of $4 \mu \mathrm{g} / \mathrm{ml} \mathrm{BSA,} 1$ unit of Amplitaq gold, and water, was prepared in the PCR set-up room of the aDNA laboratory. After the addition of template, these tubes were securely closed and transported to the main laboratory to be placed in the thermocycler. The cycling parameters used were as follows: initial denaturation for $12 \mathrm{~min}$ at $94^{\circ} \mathrm{C} ; 50$ cycles of $94^{\circ} \mathrm{C}$ for $30 \mathrm{sec}, 50^{\circ} \mathrm{C}$ for $20 \mathrm{sec}$, and $72^{\circ} \mathrm{C}$ for $30 \mathrm{sec}$; and a final extension at $72^{\circ} \mathrm{C}$ for $10 \mathrm{~min}$. Suitable PCR and extraction negatives 
Table 1. Sources of samples collected from various islands in the Seychelles. Fragments size listed below include the primers. See table 2 for details on primers used for amplification of these fragments. M: modern sample less than 50 years old; PE: preEuropean 764 to 395 BC [2-sigma (95\%) confidence interval]; x: radiocarbon age not available; m: modern sample 1806 to 1934 AD [2-sigma (95\%) confidence interval]; Y: successful amplification; N: no amplification; B: bacterial contamination; *: human contamination detected in the negative extract; -: no PCR amplification attempted; 12S: 12S rRNA; CR: control region.

\begin{tabular}{|c|c|c|c|c|c|c|c|c|}
\hline \multirow[b]{3}{*}{ Fragment size $(b p) \rightarrow$} & & \multicolumn{7}{|c|}{ Regions amplified } \\
\hline & & \multicolumn{3}{|c|}{ Cyt $-b$} & \multirow{2}{*}{$\begin{array}{l}12 S \\
450\end{array}$} & \multicolumn{3}{|c|}{$\mathrm{CR}$} \\
\hline & & 121 & 268 & 474 & & 548 & 578 & 996 \\
\hline Sample \& location & Age & & & & & & & \\
\hline 1 Silhouette & M & $\mathrm{Y}$ & $\mathrm{Y}$ & $\mathrm{Y}$ & $\mathrm{Y}$ & $\mathrm{Y}$ & $\mathrm{Y}$ & $\mathrm{N}$ \\
\hline 2 Silhouette & $\mathrm{x}$ & $\mathrm{N}$ & $\mathrm{N}$ & - & - & - & - & - \\
\hline 3 North & PE & $\mathrm{N}$ & $\mathrm{N}$ & - & - & - & - & - \\
\hline 4 Silhouette & M & $\mathrm{Y}^{*}$ & $\mathrm{Y}^{*}$ & $\mathrm{Y}^{*}$ & Y & $\mathrm{Y}$ & $\mathrm{Y}$ & $\mathrm{Y}$ \\
\hline 5 Curieuse & $\mathrm{m}$ & $\mathrm{N}$ & $\mathrm{N}$ & $\mathrm{N}$ & - & B & - & - \\
\hline
\end{tabular}

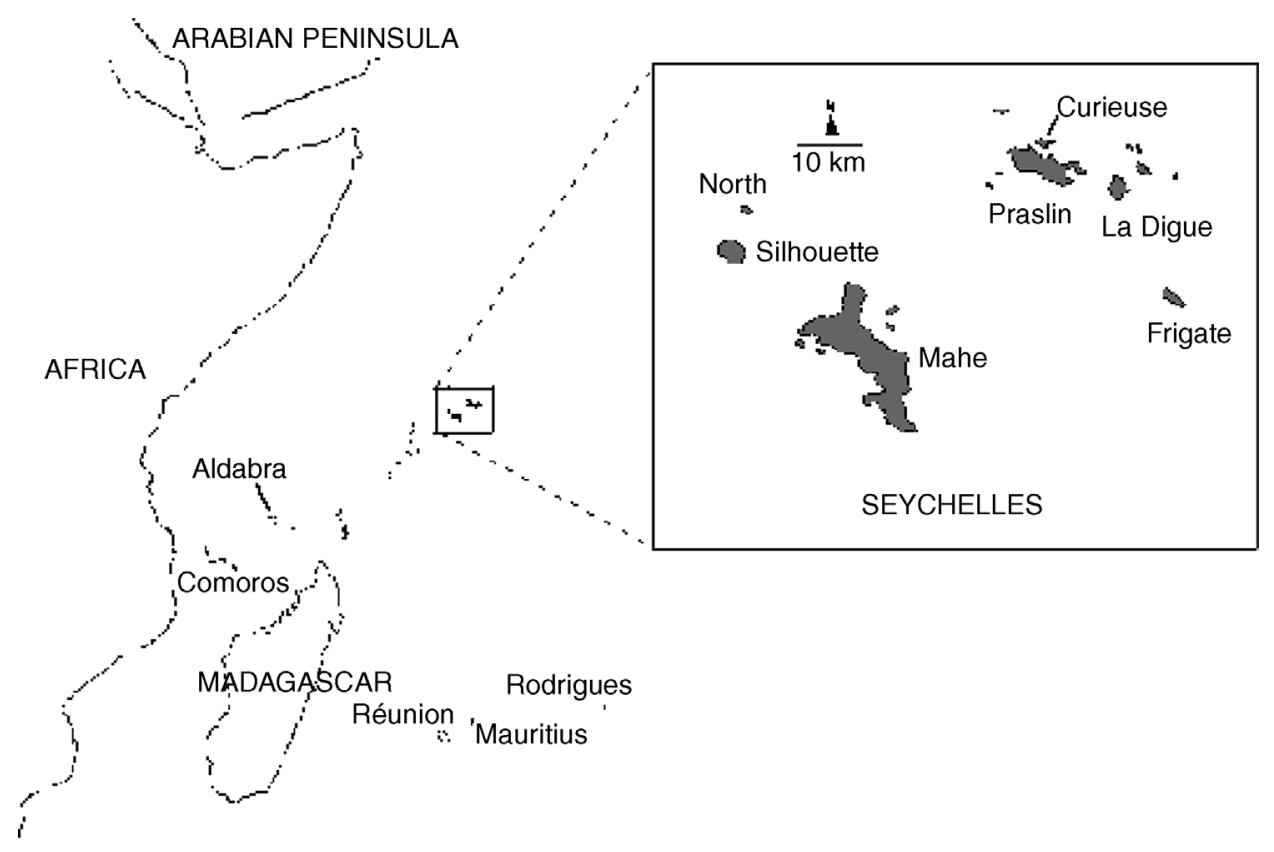

Figure 1. Map showing the islands of Western Indian Ocean. Subfossils were collected from North, Silhouette, and Curieuse islands in the Seychelles. Map modified from Palkovacs et al. (2003).

were included in every PCR. All PCR products were cloned using a TOPO cloning kit (Invitrogen). For each cloned product, between 5-9 positive clones were picked and grown overnight in LB media. The inserts were PCR-amplified directly from these clones and sequenced using the primers used in the original PCR.

If no amplifiable product was obtained for the 121 and 268 bp cyt- $b$ fragment for a particular sample, amplification of other regions were not attempted. For sample 4, DNA extraction was replicated in another clean room facility on a different floor in the same building. The extraction protocol used was the same as above, except that dispodialyzers were not used in the decalcification step. Part of the 12S rRNA gene and one of the control regions were sequenced from this extract. 
Table 2. Primers used in this study. Fragment size includes

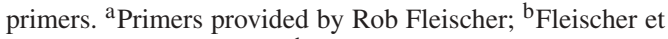
al., 2000; ' Paabo, 1990; ${ }^{\mathrm{d}}$ Kocher, 1989; ${ }^{\mathrm{e}}$ Palkovacs et al., 2003.

\begin{tabular}{|c|c|}
\hline $\begin{array}{l}\text { Fragment } \\
\text { size }\end{array}$ & Primers \\
\hline \multicolumn{2}{|c|}{ Cytochrome $b$} \\
\hline $121 \mathrm{bp}$ & $\begin{array}{l}\text { cytbS2H (5'-GAATCTACTACGGCTCATAC) } \\
\text { and cyt } b 2^{\mathrm{b}}\end{array}$ \\
\hline $268 \mathrm{bp}$ & $\begin{array}{l}\text { cytb-wow (5'-ATGGGTGGAATGGAATTTT- } \\
\text { GTC) })^{\mathrm{a}} \text { and cyt } b 2-\mathrm{rc}^{\mathrm{b}}\end{array}$ \\
\hline $474 \mathrm{bp}$ & cyt $b \mathrm{Glu}^{\mathrm{c}}$ and cyt $b \mathrm{~B} 2^{\mathrm{d}}$ \\
\hline \multicolumn{2}{|c|}{ 12S rRNA gene ${ }^{\mathrm{d}}$} \\
\hline $450 \mathrm{bp}$ & L1091 and H1478 \\
\hline \multicolumn{2}{|c|}{ Tortoise specific control region primers ${ }^{\mathrm{e}}$} \\
\hline 548 bp & Ald-DL1FR and ALD-DLBRev \\
\hline $578 \mathrm{bp}$ & ALD-DLAFor and Ald-DL2Rev \\
\hline $996 \mathrm{bp}$ & ALD-DLAFor and ALD-DLBRev \\
\hline
\end{tabular}

Only samples 1 and 4 yielded amplifiable tortoise DNA (table 1). In the case of sample 5, a product was obtained for the $548 \mathrm{bp}$ control region fragment. Upon sequencing, however, this fragment was found to be of bacterial origin. Amplification of microbial sequences from aDNA extractions may stem from post mortem colonization of the carcass by microorganisms (Höss et al., 1996). The cyt- $b$ sequences from samples 1 and 4 were identical to the most common haplotype reported for Aldabra tortoise (Austin et al., 2003). The 12S rRNA and control region sequences of these samples were also identical to the Aldabra tortoise sequences reported in earlier studies (Palkovacs et al., 2002, 2003). In the case of sample 4, identical sequences were independently obtained for $12 \mathrm{~S}$ rRNA and the control region in two labs, indicating that we were amplifying DNA endogenous to the specimen. The cyt- $b$ primers also produced bands in the negative extraction control for sample 4 (table 1). When these PCR products were cloned, and multiple clones sequenced, the same human cyt- $b$ pseudogene was recovered from all clones, indicating that the negative extract for sample 4 was contaminated with human DNA. Positive PCR reactions from sample 4 did not show contamination, however. All PCR products derived from sample 4 for these regions were also cloned and sequenced, uniformly yielding sequences that were identical to the published Aldabra tortoise sequence. All clones had the same sequence for these regions and the consensus sequence of the clones was identical to the sequences derived from direct sequencing. Additionally, clones did not exhibit consistent $\mathrm{C} / \mathrm{G} \rightarrow \mathrm{T} / \mathrm{A}$ substitution across clones at a site. Such changes can occur due to DNA damage and are often seen in aDNA studies when PCR products are cloned and multiple clones sequenced (see Hofreiter et al., 2001). Sequences are deposited in GenBank (Accession Nos. AY554042-AY554047). Results from radiocarbon dating are reported in table 1 . Samples 1, 4, and 5 are of modern origin (40-140 years old), whereas sample 3 is of pre-European origin ( $>2000$ years old).

Theoretical and empirical studies have demonstrated that DNA is best preserved in cold and dry environments protected from UV exposure (Wayne et al., 1999). Samples in this study, from which sequences were derived, were collected from tropical islands where conditions are not optimal for DNA preservation. Initially, therefore, it was surprising that we were able to amplify two of the five samples with such ready success, given our knowledge of the environmental conditions from which they were sampled, our suspicions of their pre-European antiquity, and overall weathered appearance of the specimens. We were routinely able to amplify large fragments (between 578 and 996 bp) from samples 1 and 4 . In true subfossils, on the other hand, DNA typically degrades to an average molecular size of 100-200 bp (Pääbo, 1989a; Pääbo et al., 1989b). Additionally, sequences derived from cloned PCR products showed no evidence of DNA damage often seen in other aDNA studies. Given these empirical results, we suspected that these samples must be of modern origin. As reported above, this suspicion was confirmed with radiocarbon dating (table 1). Thus, in the absence of radiocarbon dates, one might have erroneously concluded that Seychelles tortoises of putative pre- 
European origin were also derived from Aldabra tortoises. Instead, given their modern ages, we must consider the likelihood that these samples were from Aldabra tortoises brought to the Seychelles by humans. Our results therefore demonstrate the importance of radiocarbon dating of putative subfossils, prior to laboratory preparation, as opposed to assuming the antiquity of a sample based on circumstantial evidence. Obviously, "subfossils" that are found to be of recent origin must be treated as modern samples.

It is not surprising that sample 3 from North island of pre-European origin did not yield amplifiable DNA. Firstly, it is a relatively old subfossil (over 2000 years old) collected from a tropical island. Secondly, this sample was recovered from a marsh deposit. Austin and Arnold (2001) reported that DNA could be extracted from only 2 out of the 12 samples of tortoise subfossils from the marsh deposits on Mauritius. In fact, most studies that have conclusively demonstrated the ability to amplify ancient DNA have examined specimens that were preserved under low temperature and humidity. There are very few cases of successful retrieval of ancient DNA from samples collected in the tropics (for exceptions, see Yoder et al., 1999; Austin et al., 2003). Thus, it appears that a combination of antiquity and poor conditions for DNA preservation has rendered sample 3 unsuitable for aDNA studies. The radiocarbon age of sample 5 (1809-1934 AD) from Curieuse island suggests that it is of modern origin, but does not belong to the stock of Aldabra tortoises introduced in the 1970s. This island experienced extensive fires in the 1770s, which might have decimated the native tortoise population, though free-ranging tortoises were seen on this island as recently as the 1840 s. Thus, sample 5 is either derived from Aldabra tortoise introduced by European sailors and settlers as a food source (see below) or from a native Seychelles tortoise that survived the fires.

Samples 1 and 4 from which we could derive DNA sequences are both from Silhouette island where free-ranging tortoises were seen in the 1840s. But, it must be noted that after 1823 Aldabra tortoises were regularly exported to the Seychelles where local wild populations had become extinct. In later years, domesticated herds of tortoises were being maintained in at least five islands, including Silhouette and Curieuse (Stoddard et al., 1979). Thus, samples, 1, 4, and 5 probably originate from the feral populations on these islands that were intentionally introduced from Aldabra. The results of our study and others (Austin et al., 2003; Palkovacs et al., 2003) indicate that "Seychelles tortoises" from the recent past and those currently surviving in captivity may have been introduced from Aldabra. Unfortunately, the results reported herein do not shed new light on our understanding of the genetic makeup of native preEuropean Seychelles tortoises. Nonetheless, the 2000 year old radiocarbon date presented for sample 3 from North island demonstrates conclusively that native tortoises did exist on this island prior to human activities in the region. Future studies that attempt to study native Seychelles tortoises must employ radiocarbon dating, and only those specimens that are found to be older than 250 years (pre-European samples) will shed additional light on this longstanding question in tortoise evolution.

Acknowledgements. We would like to thank Robert Fleischer for providing us with cytochrome $b$ primers. We also thank James Harris for his efficient handling of the manuscript, and two anonymous reviewers for their constructive comments. This work was supported by funds from YIBSECOSAVE to A.C. and by an award from the Bay and Paul Foundations and NSF-9985205 to A.D.Y.

\section{References}

Austin, J.J., Arnold, E.N. (2001): Ancient mitochondrial DNA and morphology elucidate an extinct island radiation of Indian Ocean giant tortoises (Cylindraspis). Proc. R. Soc. Lond. B 268: 2515-2523.

Austin, J.J., Arnold, E.N., Bour, R. (2003): Was there a second adaptive radiation of giant tortoises in the Indian Ocean? Using mitochondrial DNA to investigate speciation and biogeography of Aldabrachelys (Reptilia, Testudinidae). Mol. Ecol. 12: 1415-1424. 
Austin, J.J., Smith, A.B., Thomas, R.H. (1997): Palaeontology in a molecular world: the search for authentic ancient DNA. Trends Ecol. Evol. 12: 303-306.

Bourn, D., Gibson, C., Augeri, D., Wilson, C.J., Church, J., Hay, S.I. (1999): The rise and fall of the Aldabran giant tortoise population. Proc. R. Soc. Lond. B 266: 10911100.

Fleischer, R.C., Olson, S.L., James, H.F., Cooper, A.C. (2000): Identification of the extinct Hawaiian eagle (Haliaeetus) by mtDNA sequence analysis. Auk 117: 1051-1056.

Hamber, C. (1994): Giant tortoise Geochelone gigantea translocation to Curieuse island (Seychelles): success or failure? Biological Conservation 69: 293-299.

Hofreiter, M., Jaenicke, V., Serre, D., Haeseler, A.v., Paabo, S. (2001): DNA sequences from multiple amplifications reveal artifacts induced by cytosine deamination in ancient DNA. Nucleic Acids Res. 29: 4793-4799.

Höss, M., Jaruga, P., Zastawny, T.H., Dizdaroglu, M., Paabo, S. (1996): DNA damage and DNA sequence retrieval from ancient tissues. Nucleic Acids Res. 24: 1304-1307.

Kocher, T.D., Thomas, W.K., Meyer, A., Edwards, S.V., Pääbo, S., Villablanca, F.X., Wilson, A.C. (1989): Dynamics of mitochondrial DNA evolution in mammals: Amplification and sequencing with conserved primers. Proc. Natl. Acad. Sci. USA 86: 6196-6200.

Paabo, S. (1990): Amplifying ancient DNA. In: PCR protocols: a guide to methods and applications, p. 159-166. Innis, M., Gelfand, D., Sninsky, J., White, T., Eds, San Diego, Academic Press.
Pääbo, S. (1989a): Ancient DNA: extraction, characterization, molecular cloning, and enzymatic amplification. Proc. Natl. Acad. Sci. USA 86: 1939-1943.

Pääbo, S., Higuchi, R.G., Wilson, A.C. (1989b): Ancient DNA and the polymerase chain reaction. J. Biol. Chem. 264: 9709-9712.

Palkovacs, E.P., Gerlach, J., Caccone, A. (2002): The evolutionary origin of Indian ocean tortoises (Dipsochelys). Mol. Phylogenet. Evol. 24: 216-227.

Palkovacs, E.P., Marschner, M., Ciofi, C., Gerlach, J., Caccone, A. (2003): Are native giant tortoises from the Seychelles really extinct? A genetic perspective based on mtDNA and microsatellite data. Mol. Ecol. 12: 14031413.

Stoddard, D.R., Peake, J.F., Gordon, C., Burleigh, R. (1979): Historical records of Indian Ocean giant tortoise populations. Philos. Trans. R. Soc. Lond. B 286: 147158.

Wayne, R.K., Leonard, J.A., Cooper, A. (1999): Full of sound and fury: the recent history of ancient DNA. Annu. Rev. Ecol. Syst. 30: 457-477.

Yoder, A.D., Rakotosamimanana, B., Parsons, T.J. (1999): Ancient DNA in subfossil lemurs: methodological challenges and their solutions. In: New Directions in Lemur Studies, p. 1-17. Rakotosamimanana, B., Rasaminanana, H., Ganzhorn, J., Goodman, S., Eds, New York, Plenum Press.

Received: February 10, 2004. Accepted: March 1, 2004. 